\title{
Cryptococcal Sialoadenitis in a Dog
}

\author{
Olivia Maria Moreira Borges', Valbério Brito Alves², Rosileide dos Santos Carneiro ${ }^{3}$, \\ Sabrina Barros Araujo Dantas', Rodrigo Antônio Torres Matos', Antônio Fernando de Melo Vaz', \\ Armando Marsden Lacerda Filho ${ }^{5}$ \& Almir Pereira de Souza ${ }^{4}$
}

\begin{abstract}
Background: Salivary gland diseases in dogs have an overall incidence of $0.3 \%$. Sialocele and sialoadenitis are the most common injuries and are usually caused by infectious diseases, especially of bacterial origin. Currently, Cryptococcus neoformans has not been registered as the etiological agent since fungal participation is unusual. This case report describes a cryptococcal sialoadenitis in a dog.

Case: A 1.9-year-old male poodle had a swelling of the right submandibular region, combined with dry cough and snoring that persisted for about 30 days. The dog often walked in the town square, which has pigeons, and was seen eating chicken droppings. The dog was diagnosed with sialoadenitis in the right submandibular salivary gland. The following laboratory tests were performed cytology, fungal culture, blood count, search for hemoparasites, total plasma protein (ppt), alanine aminotransferase dosage (ALT), alkaline phosphatase (ALP), urea (U), creatinine (CREA), Albumin (ALB), total protein (TP), globulin (GLOB) and amylase (AML). In addition, the dog underwent cervical, thoracic and abdominal ultrasound, and cervical x-rays. The cytology results showed fungal sialoadenitis caused by Cryptococcus neoformans. The blood test results evidenced thrombocytopenia and increased ppt, TP, GLOB, and AML. The lungs and heart x-rays results showed no alterations. However, the proximal third of the trachea was displaced ventrally. The abdominal area had no changes, but hypertrophy of the salivary gland was observed, with irregular contour, heterogeneous echotexture, and multiple cavitary areas filled with intraluminal fluid of cellular appearance. The ketoconazole $(5 \mathrm{mg} / \mathrm{kg} / \mathrm{BID} / 20$ days $)$ treatment prescribed led to drug-induced hepatitis. The new treatment with Itraconazole $(10 \mathrm{mg} / \mathrm{kg} / \mathrm{SID} / 90$ days $)$ resulted in complete clinical resolution without any side effect or relapse one year after the treatment.

Discussion: Although poodle is not commonly associated with the epidemiology of the disease, this breed seems to be susceptible, as well. The contact with pigeons during the walks was likely the source of infection by $C$. neoformans, but the ingestion of chicken droppings cannot be discarded. The coughing and snoring resulted from the pharyngeal and tracheal compression, with subsequent activation of the reflex. The clinical and laboratory findings suggest a new infection route by the etiological agent, possibly the opening of the salivary duct located in the sublingual carbuncle. Biopsy or ablation of the affected salivary gland was not necessary, reducing the risk of sepsis and/or death. Hyperamylasemia indicates that AML can be used as a complementary tool to diagnose sialoadenitis. Itraconazole administered for 90 days resulted in complete healing while no side effects or relapse was observed one year after the treatment. Cryptococcus neoformans can affect the submandibular salivary gland and, therefore, cryptococcosis should enter the differential diagnosis list of canine sialoadenitis and sialocele. Itraconazole has been shown to be effective to treat a dog with sialoadenitis caused by Cryptococcus neoformans.
\end{abstract}

Keywords: sialoadenitis, sialocele, cryptococcosis, salivary gland, dog. 


\section{INTRODUCTION}

Salivary gland diseases are not frequent in dogs, with an overall incidence of $0.3 \%$. The sialoadenitis and sialocele stand out in the list of the most common diseases, mostly involving the sublingual gland [14,29], caused commonly by trauma, immunemediated disease, sialometaplasia, foreign body, sialolithiasis, cancer, infectious diseases, aseptic and iatrogenic processes $[8,14,15,19]$. The bacterial processes stand out among the infectious causes, but fungal participation $[8,29]$ is unusual and the involvement of Cryptococcus neoformans as the etiologic agent has not been previously recorded.

Cryptococcosis affects many domestic mammals, especially cats and, less frequently, dogs [17]. The etiological agents include Cryptococcus neoformans and C. gattii, which are often found in the feces of birds and eucalyptus leaves, respectively [23]. Clinically, the disease is divided into respiratory, neurological, dermal and ophthalmic syndromes [17], while the nervous and ophthalmic involvement is highlighted in dogs $[2,4,11]$. Thus, this study reports a case of fungal sialoadenitis in a dog caused by Cryptococcus neoformans.

\section{CASE}

A male poodle, weighing $5.5 \mathrm{~kg}$ and aged 1.9 years old, was treated at the AnimalMed Veterinary Clinic in São José do Egito, PE, Brazil. The dog had an increased volume in the right submandibular region, dry cough, and snoring that had started 30 days earlier. The dog was eating normally (dog food), properly vaccinated and dewormed, had no ticks or fleas, and no changes in stool and urine. The pet had been seen eating poultry (chicken) feces and often walked in the town square, which had pigeons.

Clinically, the dog was active, in good general condition, with normal heart and respiratory rates and rectal temperature. Lymph nodes appeared normal upon palpation, mild stridor, snoring and expiratory dyspnea were observed during lung auscultation. However, a smooth swelling measuring $10 \times 6 \times 5 \mathrm{~cm}$, hot, painful, slightly irregular and with a firm, elastic consistency that presented floating areas upon palpation was observed in the right submandibular salivary gland region, characterizing sialocele with sialoadenitis (Figure 1-A).
After clinical evaluation, cytology and fungal culture of increased submandibular volume were performed. The blood count to search for hematozoa and the dosage of alanine aminotransferase (ALT), alkaline phosphatase (ALP), urea (URE), creatinine (CREA) albumin (ALB), total protein (PT), globulin (GLOB) and amylase (AML) were carried out as well. Finally, neck and chest radiography in the right laterolateral and ventral-dorsal projections, and, right cervical and abdominal ultrasonography were performed.

A Fine Needle Aspiration biopsy (FNA) was held, and $20 \mathrm{~mL}$ of moderately filiform, viscous and bright pinkish-red material (Figure 1-B) was collected. Five slides were prepared and stained by the Quick Panoptic method. Microscopic examination revealed moderate amount of individual, and sometimes aggregated, secretory epithelial cells and an intense inflammatory granulomatous process with average to large yeast structures, ranging from round to oval, with narrow base buds containing thick and clear capsules, immersed in discreetly eosinophilic amorphous material that indicated fungal-sialoadenitis caused by Cryptococcus sp. [22] (Figure 2).

The material from the affected salivary gland underwent fungal culture [10] to determine the species of Cryptococcus involved. Fungal culture and automated system (VITEK 2 Compact)1 confirmed isolation of Cryptococcus neoformans.

The blood test results showed thrombocytopenia and increased ppt, TP, GLOB and AML (Table 1 -D0). The X-rays of the thoracic region showed no lung or heart changes. However, the cervical assessment revealed a marked increase of the soft tissue adjacent to the peri-pharyngeal region, so that it ventrally displaced the proximal third of the trachea (Figure 3-A). The ultrasound showed that in the right submandibular region, the hypertrophied salivary gland had irregular contour and multiple cavitary areas filled with intraluminal fluid with cellular appearance diffusely distributed throughout the parenchyma (Figure 3-B).

After the cytological results were known, the dog started the treatment with Cetoconazol (Cetoconazol $\left.20 \%{ }^{\circledR}\right)^{2}[5 \mathrm{mg} / \mathrm{kg} / \mathrm{VO} / \mathrm{BID} / 60$ days], mineral vitamin complex $\left(\text { Organew }^{\circledR}\right)^{3}$ [2.5 g/BID/30 days], immunostimulant $\left(\text { Infervac }^{\circledR}\right)^{4}[1 \mathrm{~mL} / \mathrm{VO} / \mathrm{SID} / 3$ days] and Prednisolona (Prediderm $\left.{ }^{\circledR}\right)^{5}[2 \mathrm{mg} / \mathrm{kg} / \mathrm{VO} /$ SID/3days]. Twenty days after starting the therapy, the dog was apathetic, presented occasional vomiting, 
appetite loss with persistent dry cough and snoring, subicteric eye and oral mucous, and discrete involution of the increased thyroid volume. New blood tests were performed (Table 1 -D20), and the results showed increased ppt, ALT and FA, which along with the clinical findings, characterized drug-induced hepatitis.

The therapy was then changed to Itraconazol $\left(\mathrm{ITL}^{\circledR}\right)^{6}[5 \mathrm{mg} / \mathrm{kg} / \mathrm{BID} / 30$ days $]$, Silimarina $\left(\text { Legalon }^{\circledR}\right)^{7}$ [6 mL/VO/BID/20 days], and Metoclopramide drops $\left(\text { Plasil }^{\circledR}\right)^{8}[0.5 \mathrm{mg} / \mathrm{kg} / \mathrm{BID} / 02$ days $]$. After 30 days, the animal stopped throwing up, was feeding normally, but it still had mild dry cough and snoring. The increase of the glandular volume was reduced by $30 \%$. A new round of blood tests (Table 1 -D30) showed thrombo- cytopenia, increased ppt, PT, and GLOB, but negative for $E$. canis according to the rapid immunochromatographic test $\left(\text { Alere }^{\circledR}\right)^{9}$. It was decided to continue the treatment with Itraconazol ${ }^{6}$ [10 mg/kg/SID/30days].

Another 30 days later, the treatment was deemed successful since the clinical evolution was satisfactory due to the absence of respiratory signs and 90\% gland remission. New blood tests (Table 1 -D60) showed mild increased ppt, TP, and GLOB while AML was within the normal range. The treatment continued for another 30 days, and upon return, the animal was clinically well and without clinical and laboratory findings (Table 1 -D90). One year after the treatment there was no clinical relapse.

Table 1. Changes of the hematological and biochemical parameters in a dog with fungal sialoadenitis caused by Cryptococcus neoformans.

\begin{tabular}{|c|c|c|c|c|c|c|}
\hline \multirow{2}{*}{ Variable } & \multicolumn{5}{|c|}{ Period of evaluation and treatment (days) } & \multirow{2}{*}{ Reference Values* } \\
\hline & D0 & D20 & D30 & D60 & D90 & \\
\hline Red blood cells & 6.2 & 6.1 & 6.1 & 7.3 & 7.96 & $5.5-8.5 \mathrm{~mL} / \mathrm{mm}^{3}$ \\
\hline Hemoglobin & 13.0 & 12.8 & 13.4 & 16.9 & 18.1 & $12.0-18.0 \mathrm{~g} / \mathrm{dL}$ \\
\hline Hematocrit & 39.0 & 39.0 & 45.0 & 55.0 & 53.0 & $37.0-55.0 \%$ \\
\hline VCM & 62.9 & 63.6 & 74.0 & 75.0 & 66.6 & $60-77,0 \mathrm{fl}$ \\
\hline $\mathrm{CHCM}$ & 33.3 & 32.8 & 29.8 & 30.7 & 34.1 & $30.0-36.0 \%$ \\
\hline Leucocytes & 11,250 & 12,460 & 16,056 & 14,400 & 7,900 & $6,000-17,000 / \mathrm{mm}^{3}$ \\
\hline Myelocytes & 0 & 0 & 0 & 0 & 0 & $0-0 / \mathrm{mm}^{3}$ \\
\hline Metamyelocytes & 0 & 0 & 0 & 0 & 0 & $0-0 / \mathrm{mm}^{3}$ \\
\hline Rods & 0 & 0 & 190 & 0 & 0 & $0-510 / \mathrm{mm}^{3}$ \\
\hline Segmented & 5,560 & 9,220 & 9,160 & 9,072 & 4,266 & $3,600-3,090 / \mathrm{mm}^{3}$ \\
\hline Lymphocytes & 791 & 2,741 & 4,900 & 4,320 & 2,923 & $720-5,100 / \mathrm{mm}^{3}$ \\
\hline Monocytes & 3,842 & 374 & 1,600 & 0 & 395 & $180-1,700 / \mathrm{mm}^{3}$ \\
\hline Eosinophils & 1,017 & 125 & 206 & 1,008 & 316 & $120-1,700 / \mathrm{mm}^{3}$ \\
\hline Basophils & 0 & 0 & 0 & 0 & 0 & $0-170 / \mathrm{mm}^{3}$ \\
\hline Platelets & 189,000 & 318,000 & 190,000 & 350,000 & 280,000 & $200,000-500,000 / \mathrm{mm}^{3}$ \\
\hline ppt & 8.8 & 8.4 & 10.0 & 8.1 & 8.0 & $5.5-8 \mathrm{~g} / \mathrm{dL}$ \\
\hline Hemoparasites & negative & negative & negative & negative & negative & negative \\
\hline E. canis** & $\mathrm{nr}$ & $\mathrm{nr}$ & neg & $\mathrm{nr}$ & $\mathrm{nr}$ & negative \\
\hline PT & 7.4 & $\mathrm{nr}$ & 9.0 & 7.5 & 7.0 & $5.4-7.1 \mathrm{~g} / \mathrm{dL}$ \\
\hline ALB & 2.9 & $\mathrm{nr}$ & 2.83 & 2.8 & 3.1 & $2.6-3.3 \mathrm{~g} / \mathrm{dL}$ \\
\hline GLOB & 4.5 & $\mathrm{nr}$ & 6.17 & 4.7 & 3.9 & $2.7-4.4 \mathrm{~g} / \mathrm{dL}$ \\
\hline ALT & 22.0 & 178.0 & 36.0 & 78.0 & 17.5 & 21-102 U/L \\
\hline AP & 72.0 & 157.0 & 49.0 & 58.0 & 37.5 & $10-92 \mathrm{U} / \mathrm{L}$ \\
\hline Urea & 11.0 & $\mathrm{nr}$ & $\mathrm{nr}$ & 28.0 & 13.2 & $15-40 \mathrm{U} / \mathrm{L}$ \\
\hline Creatinine & 0.7 & $\mathrm{nr}$ & $\mathrm{nr}$ & 1.0 & 0.7 & $0.5-1.5 \mathrm{U} / \mathrm{L}$ \\
\hline AML & 760.5 & $\mathrm{nr}$ & $\mathrm{nr}$ & 601.1 & 530.0 & $185.0-700.00 \mathrm{U} / \mathrm{L}$ \\
\hline
\end{tabular}

*Kaneko et al. [6]; ppt: total plasma protein; **Imunocromatography for Erliquia canis; nr: not performed; neg: Negative; PT: total protein; ALB: Albumin; ALT: Alanine Aminotransferase; AP: Alkaline Phosphatase; AML: amylase; GLOB: globulin. 

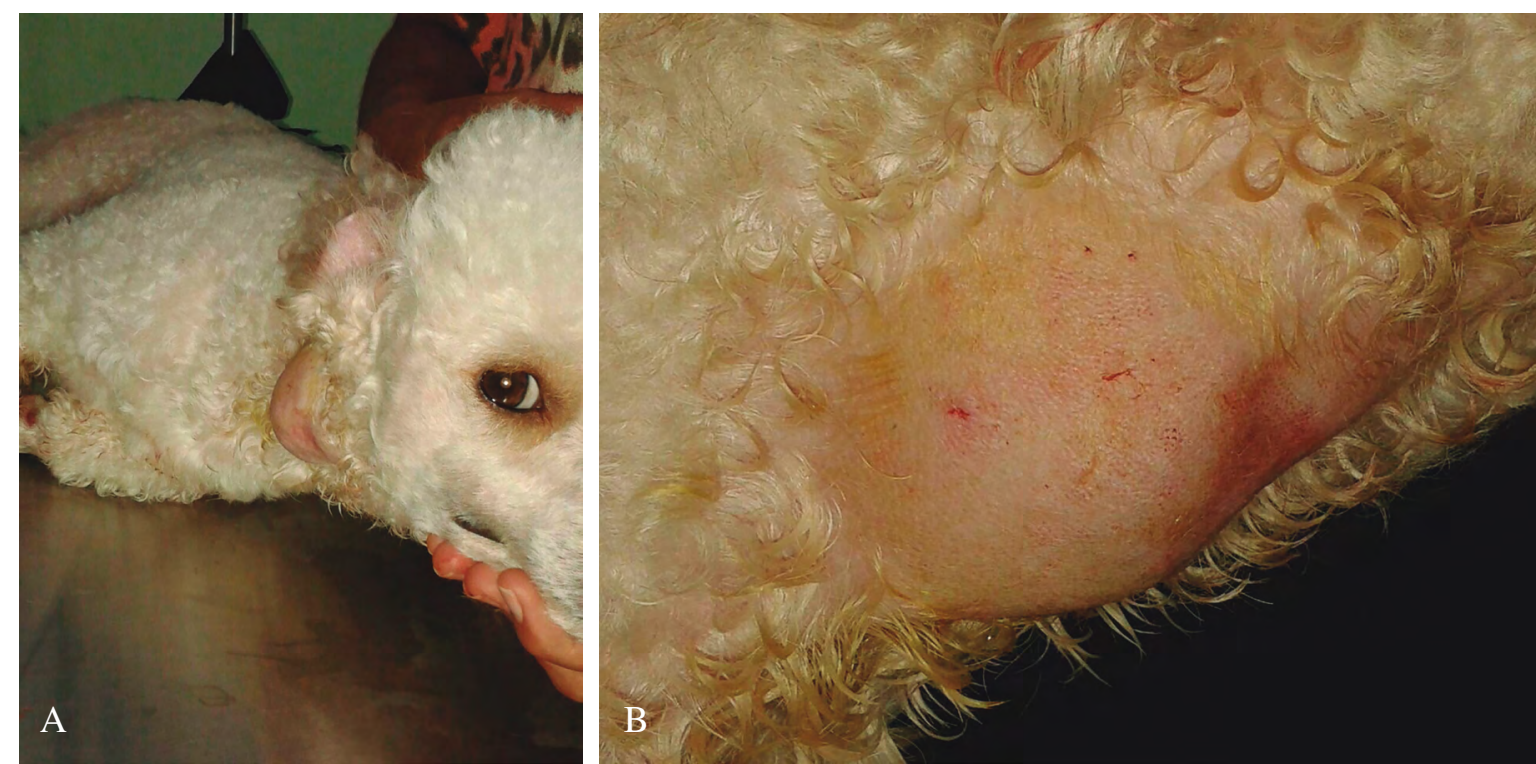

Figure 1. A- A male poodle aged 1.9 years old with sialocele. B- Appearance of the increased volume in the right submandibular region.
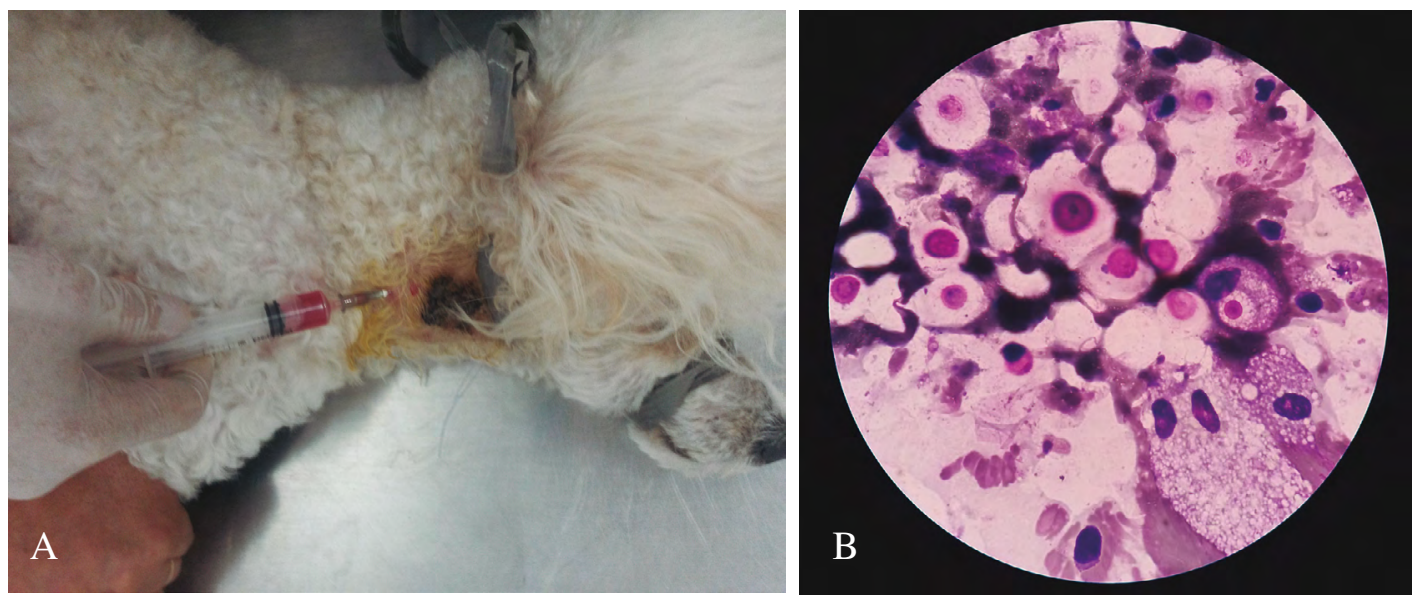

Figure 2. A- FNA in the submandibular salivary gland showing the pinkish-red colored material compatible with saliva. B- cytological aspect of the content derived from the right submandibular salivary gland of a dog with sialocele: granulomatous inflammatory process with medium to large yeast structures, ranging from round to slightly oval, with narrow base buds containing thick and clear capsules compatible with Cryptococcus sp. (fast Panoptic; $\mathrm{x} 1000$ ).
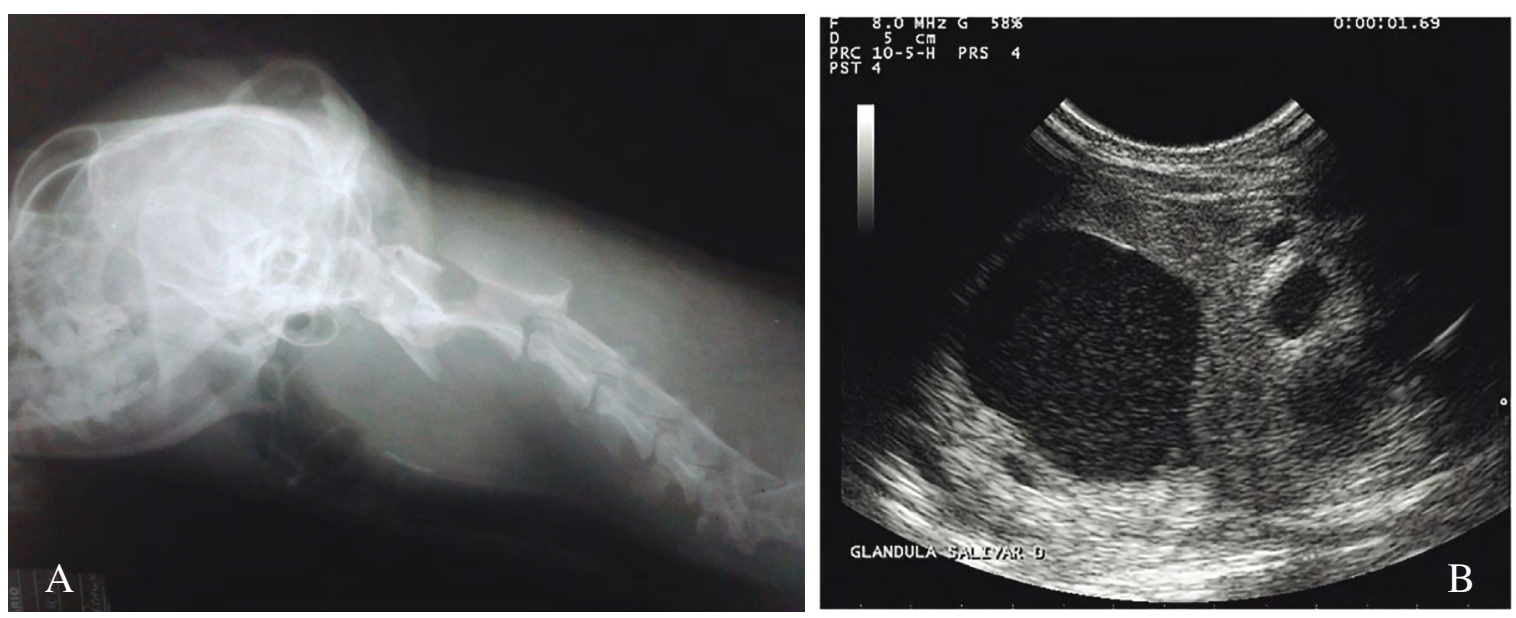

Figure 3. X-rays and ultrasound findings of a 1.9 years male poodle with fungal sialoadenitis. A- simple cervical X-ray: increased radiodensity adjacent to the peri-pharyngeal region shifting the proximal third of the trachea ventrally. B- Ultrasound of the right submandibular salivary gland: parenchyma showing irregular and heterogeneous contour, with multiple cavitary areas filled with intraluminal fluid content with a cellular aspect. 


\section{DISCUSSION}

Cryptococcosis is typically related to large breed dogs under the age of four, guard dogs, making them more susceptible to contact and development of the disease $[11,12,17]$. Although the poodle of the study was within the age range for the occurrence of the disease, the breed profile was not. Thus, demonstrating that small dogs such as poodles, with access to environments where the causative agent is present, are also susceptible to the illness.

It is likely that the frequent access to the square with pigeons was the source of infection by $C$. neoformans. Contaminated soil and bird droppings are the main sources of infection described for this agent and the pigeons assume an important role as urban reservoir [17,23]. Although C. neoformans is often linked to birds from urban environments, it is noteworthy that this dog was also in contact with poultry and was seen eating chicken droppings. Therefore, these epidemiological variables are possibly related to the development of cryptococcosis since the studied agent growth and multiplication has been correlated with compounds in poultry feces $[16,20,21]$. Also, it has been isolated from chicken droppings [18], suggesting the need for further studies related to other sources of infection by cryptococcosis.

The observed symptoms were the large increase of submandibular volume, dry cough, and snoring. A sore throat, nausea, and vomiting or regurgitation are commonly observed symptoms when sialoadenitis and sialocele affect the mandibular or parotid glands [7]. In this case, in the absence of these changes and radiographic findings that could justify bronchitis and/or fungal pneumonia, the clinical symptoms of coughing and snoring were linked to the activation of the reflex by the pharyngeal and tracheal compression arising from the sialoadenitis and sialocele ( Figure 3 -A). This possibility can be further elucidated by the disappearance of these clinical symptoms as the treatment progressed.

It was possible to observe a clinical symptom of sialoadenitis and sialocele, a condition that so far has not been associated with cryptococcosis in animals or humans. The dogs present clinical neurological, ophthalmic, respiratory symptoms and occasionally cutaneous involvement, which may be isolated or related $[2,4,17]$. This fact highlights the new clinical presentation of canine cryptococcosis observed in this case.
The unilateral sialoadenitis, no alterations in the skin of the glandular region, no changes in the thoracic radiographs and abdominal ultrasound, and the absence of other clinical symptoms $[4,17]$ excluded the systemic involvement and inhalation as a route of infection, and supported the hypothesis of a new gateway [3]. Thus, the anatomical basis of the sublingual and submandibular salivary gland [13] supported the hypothesis that accidental ingestion of pigeon and/ or poultry droppings with Cryptococcus neoformans propagules entered the salivary duct opening, located at the sublingual caruncle, migrated through this duct and installed in the right submandibular salivary gland. Once installed, the agent virulence factors [3,23] caused sialoadenitis, resulting in the obstruction of the salivary drainage channel to the oral cavity and forming the sialocele.

Several factors have been primarily associated with cryptococcosis in animals: weakness, stress, malnutrition, prolonged use of corticosteroids, malignancies, and infectious viral and bacterial processes [4]. In this case, the clinical profile and the cyclic thrombocytopenia (Table 1) presented by the animal, can be associated with subclinical ehrlichiosis caused by E. platys [6], suggesting this disease as the basis in this case.

Cryptococcosis is often diagnosed post-mortem [1]. In this case, the diagnosis of fungal sialoadenitis by Cryptococcus neoformans was achieved by cytological and microbiological [2,22] examination. It was not necessary to refer the patient to biopsy or ablation of the gland, the usual procedure to treat sialocele [15], helping to reduce the risks of contamination, sepsis and death, occasionally observed in procedures when infectious diseases are involved [2].

The most common hematologic abnormalities in the presence of cryptococcosis are non-regenerative anemia, monocytosis, and lymphopenia $[5,30]$. In this case, in addition to monocytosis, hyperamylasemia, increased ppt, hyperproteinemia and hyperglobulinemia (Table 1) were also observed. The increased ppt, $\mathrm{TP}$, and GLOB is associated with immune-mediated diseases, chronic inflammatory and infectious processes in response to an immunological activation and mediation [9].

AML is not commonly used as a tool to detect changes in the salivary gland; it is most frequently used in cases of acute pancreatitis, decreased glomerular 
filtration mapping and brain trauma [27]. In this case, hyperamylasemia in the absence of pancreatitis, renal and cerebral alterations was used as a complementary diagnostic tool of the inflammatory process of the affected salivary gland.

The therapeutic protocol adopted for sialoadenitis caused by Cryptococcus neoformans was effective, and the patient recovered after 110 days of treatment. Drug-induced hepatitis observed in the initial 20 days was linked to the use of Ketoconazole. Although this medicament is described as effective to treat cryptococcosis, it can lead to hepatotoxicity $[24,25,28,31]$. In this case, it becomes necessary to suspend its use and introduce a new protocol. Itraconazole has broad spectrum and reduced toxic effect albeit there are few studies regarding the duration of treatment, side effects and costs $[11,26]$. The use of Itraconazole for 90 days resulted in complete resolution of the disease while no side effects were observed nor relapse one year after treatment.
In conclusion, Cryptococcus neoformans can affect the submandibular salivary gland, which must be considered as an atypical site for the disease. The cryptococcosis should go on the list of differential diagnoses of sialoadenitis and sialocele in dogs. Itraconazole has been shown to be effective to treat sialoadenitis caused by Cryptococcus neoformans in a dog.

\section{MANUFACTURERS}

${ }^{1}$ Biomerieux. Durham, NC, USA.

${ }^{2}$ Ibasa Ltda. Porto Alegre, RS, Brazil.

${ }^{3}$ Vetnil Ltda. Louveira SP, Brazil.

${ }^{4}$ Hertape Calier Ltda. Juatuba, MG, Brazil.

${ }^{5}$ Ourofino Ltda. Cravinhos, SP, Brazil.

${ }^{6}$ CEPAV Pharma Ltda. São Paulo, SP, Brazil.

${ }^{7}$ Nycomed Ltda. Santo Amaro, SP, Brazil.

${ }^{8}$ Ems Sigma Pharma Ltda. Carapicuiba, SP, Brazil.

${ }^{9}$ Alere ${ }^{\circledR}$ SA. São Paulo, SP, Brazil.

Declaration of interest. The authors report no conflicts of interest. The authors alone are responsible for the content and writing of the paper.

\section{REFERENCES}

1 Alessi A.C., Benato N., Camacho A.A., Honsho C.S., Laus J.L., Mine S.Y. \& Oriá A.P. 2003. Generalized systemic cryptococcosis in a dog after immunosuppressive corticotherapy. Arquivo Brasileiro de Medicina Veterinária e Zootecnia. 55(2): 155-159.

2 Barbosa A.L.T., Cavalheiro A., Lopes S.T.A., Martins D.B., Mazzanti A., Santurio J.M. \& Schossler J.E. 2008. Diagnóstico de criptococose canina pela citologia aspirativa por agulha fina. Ciência Rural. 38(3): 826-829.

3 Barros C.S.L., Kommers G.D., La Corte F.D., Souto M.A.M. \& Souza T.M. 2005. Granulomatous cryptococcal pneumonia in a horse. Ciência Rural. 35(4): 938-940.

4 Barros P.S.M., Gambale W., Larsson C.E., Michalany N.S., Otsuka M. \& Safatle A.M.V. 2003. Criptococose canina: relato de caso. Arquivo Brasileiro de Medicina Veterinária e Zootecnia. 55(5): 533-538.

5 Bartlett K.H., Duncan C.G., Lester S.J. \& Malik R. 2011. Cryptococcosis: update and emergence of Cryptococcus gattii. Veterinary Clinical Pathology. 40(1): 4-17.

6 Benedetti R.B.R., Coppede J.S., Lucas F., Marins M., Oliveira L.P., Pereira A.L.A., Roberto P.G., Santos F., Sobreira L. \& Zucoloto L.B. 2009. Molecular evaluation of the incidence of Ehrlichia canis, Anaplasma platys and Babesia spp. in dogs from Ribeirão Preto, Brazil. The Veterinary Journal. 179(1): 145-148.

7 Berry W.L. \& Schroeder H. 1998. Salivary gland necrosis in dogs: a retrospective study of 19 cases. Journal of Small Animal Practice. 39(3): 121-125.

8 Bradley P.J. 2002. Microbiology and management of sialoadenitis. Current Infectious Disease Reports. 4(3): 217-224.

9 Bruss M.L., Harvey J.W. \& Kaneko J.J. 2008. Clinical Biochemistry of Domestic Animals. 6th edn. Rio de Janeiro: Elsevier, 905p.

10 Carter M.E., Donnelly W.J., Quinn P.J., Markey B.K. \& Leonard F.C. 2005. Microbiologia veterinária e doenças infecciosas. Porto Alegre: Artmed, 499p.

11 Coutinho S.D.A. \& Pereira A.P.C. 2003. Criptococose em cães e gatos - revisão. Revista Clínica Veterinária. 8(45): 24-32.

12 Dill-macky E., Love D.N., Malik R., Martin P., Muir D.B. \& Wigney D.I. 1995. Cryptococcosis in dogs: a retrospective study of 20 consecutive cases. Journal of Medical and Veterinary Mycology. 33(5): 291-297.

13 Dyce K.M., Sack W.O. \& Wensing C.J.G. 2010. Tratado de anatomia veterinária. 4.ed. Rio de Janeiro: Elsevier, 840 p. 
14 Estepa J.C., Mendoza F.J. \& Perez-ecija A. 2012. Granulomatous giant cell submandibular sialoadenitis in a dog. Canadian Veterinary Journal. 53(11): 1211-1213.

15 Fossum T.W. \& Hedlund C.S. 2007. Surgery of the Oral Cavity and Oropharynx. In: Fossum T.W. (Ed). Small Animal Surgery. 3rd edn. St. Louis: Mosby Elsevier, pp.339-371.

16 Hubalek Z. 1975. Distribution of Cryptococcus neoformans in a pigeon habitat. Folia Parasitologica. 22(1): 73-79.

17 Izael M.A., Lage R.A., Queiroz J.P.A.F., Santos A.G. \& Sousa F.D.N. 2008. Criptococose - uma revisão. Acta Veterinaria Brasilica. 2(2): 32-38.

18 Kayembe K., Niyimi M. \& Swinne D. 1986. Isolation of saprophytic Cryptococcus neoformans var. neoformans in Kinshasa, Zaire. Annales de la Société Belge de Médicine Tropicale. 66(1): 57-61.

19 Lester N., Mansfield C., Mcgill S. \& Mclachlan A. 2009. Concurrent sialocoele and necrotizing sialoadenitis in a dog. Journal of small animal practice. 50(3): 151-156.

20 Levitz S.M. 1991. The ecology of Cryptococcus neoformans and the epidemiology of cryptococcosis. Reviews of Infectious Diseases. 13(6): 1163-1169.

21 Mendes-Giannini M.J., Raso T.F. \& Werther K. 2004. Cryptococcosis outbreak in psittacine birds in Brazil. Medical Mycology. 42(4): 355-362.

22 Meyer D.J. \& Raskin R.E. 2011. Atlas de citologia de cães e gatos. 2.ed. Rio de Janeiro: Elsevier, 472p.

23 Mezzari A., Perez L.R.R. \& Reolon A. 2004. Prevalência de Cryptococcus neoformans nos pombos urbanos da cidade de Porto Alegre, Rio Grande do Sul. Jornal Brasileiro de Patologia e Medicina Laboratorial. 40(5): 293-298.

24 Moriello K.A. 1986. Ketoconazole: clinical pharmacologic and therapeutic recommendations. Journal of the American Veterinary Medical Association. 188(3): 303-306.

25 Nobre M.O., Nascente P.S., Meireles M.C. \& Ferreiro L. 2002. Drogas antifúngicas para pequenos e grandes animais. Ciência Rural. 32(1): 175-184.

26 O'toole T.E., Rozansky E.A. \& Sato A.F. 2003. Cryptococcosis of the central nervous system in a dog. Journal of the American Veterinary Medical Association. 222(12): 1722-1725.

27 Onyesom I., Osioma E. \& Ugbebor S. 2012. Alpha amylase activity in saliva of humans infected with Plasmodium falciparum malaria. Archives of Applied Science Research. 4(3): 1227-1230.

28 Sherding R.G. 2008. Micoses sistêmicas. In: Bichard S.J. \& Sherding R.G(Eds). Manual Saunders: Clínica de pequenos animais. 3.ed. São Paulo: Roca, pp.209-222.

29 Spangler W. \& Culbertson M.R. 1991. Salivary gland disease in dogs and cats: 245 cases (1985-1988). Journal of the American Veterinary Medical Association. 198(3): 465-469.

30 Taboada J. 2004. Micoses Sistêmicas. In: Ettinger S.J. \& Feldman E.C. (Eds). Tratado de Medicina Interna Veterinária: doenças do cão e do gato. 5.ed. Rio de Janeiro: Guanabara Koogan, pp.478-503.

31 Thomson P., Miranda G. \& Silva V. 2006. Linfadenitis canina producida por Cryptococcus neoformans - Primer caso in Chile. Revista Iberoamericana de Micología. 23: 238-240. 